\title{
Musa acuminata PSEUDOSTEM EXTRACT ON THE CONTROL OF Atta sexdens rubropilosa
}

\author{
EXTRATO DE PSEUDOCAULE DE Musa acuminata NO CONTROLE DE Atta \\ sexdens rubropilosa
}

\section{Thais Cibeli da SILVA ${ }^{1}$; Alcilene Batista de CAMARGOㅜㄹ Laura Araújo SANCHES $^{2 *}$; Juliana GARLET ${ }^{3}$}

1. Engenheira Florestal, Universidade do Estado de Mato Grosso, Campus II - Av. Perimetral Rogério Silva, s/n-Jardim Flamboyant, Alta Floresta, Mato Grosso; 2. Engenheira Florestal, Mestranda em Biodiversidade e Agroecossistemas Amazônicos, Universidade do Estado de Mato Grosso, Campus II - Av. Perimetral Rogério Silva, s/n-Jardim Flamboyant, Alta Floresta, Mato Grosso; laura_araujo_@hotmail.com; 3. Professora, Dra. da Faculdade de Ciências Biológicas e Agrárias da Universidade do Estado de Mato Grosso, Campus II - Av. Perimetral Rogério Silva, s/n-Jardim Flamboyant, Alta Floresta, Mato Grosso.

\begin{abstract}
Currently, few active principles are authorized by the forest certification for the control of insect pests, with which it is necessary to develop new products, mainly aiming at lower environmental impact. The plants are able to develop substances called secondary metabolites, widely studied as an alternative form of pest control. Thus, the objective of this study was to evaluate the insecticidal potential of two Musa acuminata extracts, on the control of Atta sexdens rubropilosa. The extracts were obtained from the pseudostem of M. acuminata, which underwent drying and milling, producing two extracts: ethanolic (A1) and hydroethanolic rotaevaporate (A2) extract. For the analysis of the bioactivity of the extracts, a topical application of one milliliter of each extract on the ants was carried out, with the aid of spray, in the concentrations of: $2,6,10,14,18$, and $20 \%$, with distilled water (witness) applied to the test, analyzing the mortality and $\mathrm{LC}_{50}$, in different evaluation periods. At 24 hours the mortality of $90 \%$ at the concentration of $20 \%$ for the A1 extract was observed. From the $10 \%$ concentration there was $100 \%$ mortality in this same period for the A2 extract, and at 48 hours the $2 \%$ concentration caused $100 \%$ mortality. In the $\mathrm{LC}_{50}$ analysis for 24 hours values of 7.94 and 1.09\% were obtained for ethanolic extract and rotavaporated ethanolic extract respectively. And the $\mathrm{LC}_{50}$ presented a decrease in values after 48 hours for the ethanolic extract presented value of $2.29 \%$. Thus, it can be concluded that the A2 extract is the most efficient, since it allows the lower consumption of extract in the dilution for later application, due to the presence of insecticidal potential in low concentration.
\end{abstract}

KEYWORKS: Solid waste. Secondary metabolite. Insecticide. Forest entomology.

\section{INTRODUCTION}

Cutting ants are American insects and scatter throughout Central and South America, except Chile. In Brazil there are 20 species and nine subspecies of Acromyrmex, ten species and three subspecies of Atta. Among the species that cause greater damages is the saúva lemon (Atta sexdens Forel) which has a wide distribution in the Brazilian territory. The habit of cutting leaves characterizes the leaf-cutting ants as the main plagues of forest and agricultural plantations, even destroying a culture totally or partially (HEBLING et al., 2000; DELABIE et al, 2011; OLIVEIRA et al., 2018).

Currently in Brazil, the control of leaf cutting ants has been carried out with the application of formicidal baits, mainly based on Sulfluramide. However, the use of chemical control for insect-pest control in general has been questioned by the negative impacts it can cause to the environment.
And in the forestry sector the forest certification required by some countries for export has further restricted the use of these chemicals. Few active principles are authorized by forest certification for pest control, and The FSC (Forest Stewardship Council) has restricted the use of the main active principles used to control forest pests in Brazil, including Fipronil, Deltrametrin, and Sulfluramide (JUNG et al., 2013).

With the restriction and scarcity of insecticides registered, it is essential to develop and register new products for control. Since ancient times the properties present in plants used in medicine and against insects have been known (ARRAIS et al., 2014). Studies of pest control with plant-derived products were resumed in the early 1960s, with a concern to protect the environment. Although studies have been resumed using plants, chemical insecticides have still been used to control ants, which can have negative effects on the 
environment and on humans (SOUZA-SILVA et al., 2005).

Plant insecticides are obtained from extractives, substances resulting from the secondary metabolism of plants that, according to chemical and ecological studies, play an important protective role in insects' interactions with plants (VIGLIANCO et al., 2008), which can be obtained from various parts of the plant, such as the leaf, fruit, stem, or root, and its function is the defense of plant species against herbivorous insects (TAVARES; VENDRAMIM, 2005).

The exploitation of bioactive secondary compounds present in the crude extract or essential oils of plants can be efficient in pest control. In this way, the pseudostem of banana (Musa acuminata) was selected for this study, in addition to a proposal of reuse of solid waste from fruit production. According to Souza et al. (2010) for each ton of industrialized banana, approximately three tons of pseudocaule and $480 \mathrm{~kg}$ of leaves are generated.

The study of banana pseudostem extract $(M$. acuminata) aims beyond the use of the production residue, reducing the use of organosynthetic insecticides that contaminate and interfere with the environment, becoming a sustainable way to solve two different problems. The objective of the study was to evaluate the insecticidal potential of two extracts of Musa acuminata, for the control of Atta sexdens rubropilosa.

The hypotheses tested in this study are: I) that the pseudostem of Musa acuminata has an insecticidal effect, due to work already done that verified the presence of secondary metabolites with insecticidal power; and, II) that the hydroethanolic rotaevaporate extract is more efficient than the ethanolic extract.

\section{MATERIAL AND METHODS}

The study was conducted in a laboratory at the State University of Mato Grosso, Alta Floresta Campus - MT, located between coordinates $9^{\circ} 51^{\prime}$ $39.44^{\prime \prime} \mathrm{S}$ and $56^{\circ} 04^{\prime} 7.38^{\prime \prime} \mathrm{W}$. The selected plant material (pseudostem) was obtained from the banana tree ( $M$. acuminata) harvested in the rural area of Alta Floresta - MT, which was sectioned and cut in slices, dried in an oven with forced air circulation at $45{ }^{\circ} \mathrm{C}$ for $72 \mathrm{~h}$, after drying, the material was crushed in a processor.

To obtain the ethanolic extract (A1), 20 grams of the dry and crushed material was used, and 100 milliliters of ethanol (92.8\%) was added, this solution was brought to the water bath for 15 minutes at a temperature of $60{ }^{\circ} \mathrm{C}$, often during this period, to facilitate the extraction of the substances present in the material. Subsequently, void filtration was carried out, the liquid obtained was filled into a clean bottle and stored in a cool, dry place protected from light.

In order to obtain the crude hydroethanolic extract (A2) a new extract was produced, in which $100 \mathrm{~g}$ of dry and crushed material was conditioned and one liter of $70 \%$ alcohol. The solution was stored in a glass bottle for seven days and stirred periodically. The bottle was protected from light. Subsequently, the filtration was performed in fine tissue (voil), the liquid extract was rotated and lyophilized to obtain the extract A2.

In the experiment, ten leaf-cutting ants were allocated, five soldiers and five workers along with a solid diet, in glass vials, sealed with voil, for air passage. To prepare the diet, three grams of dextrose, one grams of food agar, and 100 milliliters of distilled water were used as recommended by Jung et al. (2013).

The components were mixed and microwaved for three minutes, the diet was packed into petri dishes and stored in a refrigerator until the time of bioassay implantation. The solidified diet was cut into cubes and placed in the glasses. During the evaluation period, the diet was renewed when necessary.

To analyze the bioactivity of the extracts, a topical application of one milliliter of extract on the ants (contact) was carried out with the aid of a sprayer in the concentrations of 2, 6, 10, 14, 18, and $20 \%$ and a witness $(0 \%)$ of distilled water was applied. For each concentration, five replicates were arranged with ten ants each, comprising five workers and five soldiers, kept in an air-conditioned room. At $26 \pm 2{ }^{\circ} \mathrm{C}, \mathrm{U}$. R. of $60 \pm 10 \%$ and photo phase of 12 hours. The concentrations used were the same for both A1 and A2 extracts.

The evaluations were carried out in a period of 72 hours, quantifying the number of dead ants (\% of mortality), in the periods of $4,24,48,56$, and 72 hours. This was the factorial experiment $(2 \times 7)$, with two ways of obtaining extracts, and seven different concentrations. The data were transformed into arcsen $\sqrt{\mathrm{x}}_{\mathrm{x}} / 100$, to meet the normality assumption and later submitted to an analysis of variance (Test $\mathrm{F}$ ), the means being compared by the Tukey test $(\mathrm{p}<0.01)$, with the aid of Statistical Program Assistat version 7.7 beta (SILVA; AZEVEDO, 2016). The calculation of $\mathrm{LC}_{50}$ was performed. by means of the Probit curve. 


\section{RESULTS AND DISCUSSION}

The Table 1 shows the average percentages of mortality of $A$. sexdens rubropilosa at different exposure times and extract concentrations.

Table 1. Mean percentage of mortality of A. sexdens rubropilosa by topical application of extracts of $M$. acuminata in different concentrations.

\begin{tabular}{|c|c|c|c|c|c|c|}
\hline \multirow{2}{*}{$\mathrm{C} \%$} & \multicolumn{2}{|l|}{$4 \mathrm{~h}$} & \multicolumn{2}{|l|}{$24 \mathrm{~h}$} & \multicolumn{2}{|l|}{$48 \mathrm{~h}$} \\
\hline & A1 & A2 & A1 & A2 & A1 & A2 \\
\hline B1 & $0 \pm 0,0 \mathrm{aC}$ & $2 \pm 0,72 \mathrm{aC}$ & $28 \pm 7,42 \mathrm{aB}$ & $16 \pm 7,61 \mathrm{aB}$ & $64 \pm 5,25 \mathrm{aB}$ & $62 \pm 5,33 \mathrm{aB}$ \\
\hline B2 & $0 \pm 0,0 \mathrm{bC}$ & $36 \pm 8,38 \mathrm{aB}$ & $28 \pm 7,38 \mathrm{bB}$ & $78 \pm 5,18$ aA & $60 \pm 5,21 \mathrm{bB}$ & $100 \pm 0,0 \mathrm{aA}$ \\
\hline B3 & $8 \pm 8,3 \mathrm{bBC}$ & $48 \pm 6,28 \mathrm{aAB}$ & $32 \pm 6,32 \mathrm{bB}$ & $84 \pm 4,11 \mathrm{aA}$ & $64 \pm 5,23 \mathrm{bB}$ & $98 \pm 3,11 \mathrm{aAB}$ \\
\hline B4 & $12 \pm 8,65 \mathrm{bBC}$ & $54 \pm 6,22 \mathrm{aAB}$ & $60 \pm 5,25 \mathrm{bAB}$ & $100 \pm 0,0 \mathrm{aA}$ & $76 \pm 4,22 \mathrm{bAB}$ & $100 \pm 0,0 \mathrm{aA}$ \\
\hline B5 & $0 \pm 0,0 \mathrm{bC}$ & $58 \pm 6,21 \mathrm{aAB}$ & $40 \pm 4,28 \mathrm{bB}$ & $100 \pm 0,0 \mathrm{aA}$ & $76 \pm 4,19 \mathrm{bAB}$ & $100 \pm 0,0 \mathrm{aA}$ \\
\hline B6 & $20 \pm 7,45$ bAB & $70 \pm 5,18 \mathrm{aA}$ & $58 \pm 5,31$ bAB & $100 \pm 0,0 \mathrm{aA}$ & $94 \pm 3,12 \mathrm{aA}$ & $100 \pm 0,0 \mathrm{aA}$ \\
\hline B7 & $46 \pm 6,34 \mathrm{aA}$ & $60 \pm 6,19 \mathrm{aAB}$ & $90 \pm 3,18$ aA & $100 \pm 0,0 \mathrm{aA}$ & $100 \pm 0,0 \mathrm{aA}$ & $100 \pm 0,0 \mathrm{aA}$ \\
\hline $\mathrm{Cv}(\%)$ & 37,10 & & 28,17 & & 18,11 & \\
\hline $\mathrm{LC}_{50}(\%)$ & 22,5 & 6,02 & 7,94 & 1,09 & 2,29 & 1,09 \\
\hline
\end{tabular}

$\mathrm{h}=$ hour; $\mathrm{A} 1=$ ethanolic extract; $\mathrm{A} 2=$ rotavaporated ethanolic extract; $\mathrm{B} 1=$ witness; $\mathrm{B} 2=2 \%$; $\mathrm{B} 3=6 \% ; \mathrm{B} 4=10 \% ; \mathrm{B} 5=14 \% ; \mathrm{B} 6=$ $18 \%$ and $\mathrm{B} 7=20 \%$. Means followed by the same capital letter in the column, and lowercase in the row in each evaluation period, do not differ by Tukey test $(\mathrm{p}<0.01)$.

As the interaction was not significant between the factors, the 56 and 72 hours evaluation times were analyzed separately, according to Table 2.

Table 2. Average percentage of mortality of A. sexdens rubropilosa by topical application of extracts of $M$. acuminata, in different concentrations in the periods of 56 and 72 hours of exposure.

\begin{tabular}{lcclc}
\hline C\% & \multicolumn{1}{c}{$\mathbf{5 6} \mathbf{h}$} & \multicolumn{2}{l}{$\mathbf{7 2 h}$} \\
\cline { 2 - 5 } & \multicolumn{1}{c}{$\mathbf{A 1}$} & $\mathbf{A 2}$ & $\mathbf{A 1}$ & $\mathbf{A 2}$ \\
\hline B1 & $72 \pm 5,21 \mathrm{a}$ & $78 \pm 4,2 \mathrm{~b}$ & $82 \pm 6,17 \mathrm{a}$ & $82 \pm 4,11 \mathrm{~b}$ \\
B2 & $76 \pm 6,23 \mathrm{a}$ & $100 \pm 0,0 \mathrm{a}$ & $84 \pm 4,11 \mathrm{a}$ & $100 \pm 0,0 \mathrm{a}$ \\
B3 & $68 \pm 5,26 \mathrm{a}$ & $98 \pm 3,02 \mathrm{a}$ & $86 \pm 4,13 \mathrm{a}$ & $98 \pm 3,02 \mathrm{a}$ \\
B4 & $80 \pm 4,22 \mathrm{a}$ & $100 \pm 0,0 \mathrm{a}$ & $88 \pm 4,14 \mathrm{a}$ & $100 \pm 0,0 \mathrm{a}$ \\
B5 & $80 \pm 4,19 \mathrm{a}$ & $100 \pm 0,0 \mathrm{a}$ & $88 \pm 4,12 \mathrm{a}$ & $100 \pm 0,0 \mathrm{a}$ \\
B6 & $94 \pm 3,12 \mathrm{a}$ & $100 \pm 0,0 \mathrm{a}$ & $96 \pm 3,02 \mathrm{a}$ & $100 \pm 0,0 \mathrm{a}$ \\
B7 & $100 \pm 0,0 \mathrm{a}$ & $100 \pm 0,0 \mathrm{a}$ & $100 \pm 0,0 \mathrm{a}$ & $100 \pm 0,0 \mathrm{a}$ \\
\hline Cv (\%) & 25,33 & 8,25 & 21,67 & 7,29 \\
\hline LC & & 1,09 & 1,65 & 1,09
\end{tabular}

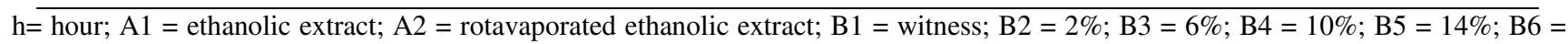
$18 \%$ and $\mathrm{B} 7=20 \%$. Means followed by the same capital letter in the column, and lowercase in the row in each evaluation period, do not differ by Tukey test $(\mathrm{p}<0.01)$. 
In the first four hours of the bioassay, there was a significant difference only for the concentration of $20 \%$ in the application of A1 extract (Table 1). According to Lima Neto (2015), ethanolic extracts have lower contents of metabolites when compared to the rotated dry extract. Increasing the concentration increases the potential of efficiency in the application, corroborating with the one observed in this study for the extract A1 (Table 1).

In the diluted A2 extract, there was a significant difference only in the concentration of $18 \%$ after four hours of exposure. The relationship between extracts: A1 and A2 for the four-hour period showed a significant difference in practically all concentrations, except for $20 \%$.

For the evaluations at 24 hours in relation to the different concentrations analyzed, the A1 extract showed a significant difference for the concentration of $20 \%$, where it caused a mortality of $90 \%$ of the individuals. Although authors such as Silva et al. (2008) and Lima Neto (2015) affirm the low content of bioactive, the extract A1 can be used, but in a higher concentration, as observed in this study. Carvalho et al. (2015) observed a mortality of 99.2\% of Aedes aegypti individuals in the 24-hour period, for aqueous extract of Croton tetradenius dried leaves obtained by maceration, a result similar to that was obtained for the A1 extract of Musa acuminata pseudostem.

The A2 extract provided a significant difference in concentrations of 2 and $6 \%$ with 78 and $84 \%$ mortality, respectively, in the 24-hour evaluation. From the $10 \%$ concentration, 100 percent mortality was obtained at concentrations of $10,14,18$, and $20 \%$ (Table 1). It can be observed that in low concentrations the extract A2 already has insecticidal potential, as observed in the interaction between extracts, where all the concentrations differed, demonstrating the greater efficiency for the extract A2.

According to Silva et al. (2008) extracts in the form of powder (rotaevaporated) have a higher concentration of bioactive compounds, elucidating the mortality of $100 \%$ of the individuals in this period. At 48 hours there was a significant difference for the $\mathrm{A} 1$ extract at the concentrations of 18 and $20 \%$ with 94 and $100 \%$ of mortality, respectively, whereas for the $\mathrm{A} 2$ extract there was a significant difference only at the $2 \%$ concentration (Table 1).
The results obtained for the 48 hours can be explained by the longer time of contact effect of the extracts in higher concentrations for extract $\mathrm{A} 1$ and in the smaller ones for extract A2, which, according to Lima Neto (2015), present a lower content of metabolites (bioactive) and may take longer to take effect. In the period of 48 hours there was a significant difference between extracts at concentrations of $2,6,10$, and $14 \%$.

The readings in the 56 and 72 hours periods did not present a significant difference in mortality (Table 2), since in almost all treatments there was $100 \%$ mortality of the individuals at 24 hours for the A2 extract. Rodrigues et al. (2014) also did not observe a significant difference in mortality of Aphis craccivora between 48 and 72 hours, for hexane extract of seeds of the species Annona muricata L. since in the bioassays, also presenting significant mortality at 24 hours.

Therefore, the extract of Musa acuminata was efficient since other authors such as Souza et al. (2012) and Jung et al. (2013) obtained satisfactory results in a longer period of time. These authors tested different methods of obtaining extracts in a period of 20 days (Atta sexdens) and five days (Atta laevigata), respectively. Characterizing, in this study, the high efficiency, especially for the A2 extract, since the topical application presented significant mortalities in the period of 24 hours of evaluation.

Analyzing the $\mathrm{LC}_{50}$ (Table 1), it can be observed that the value found for the rotated vaporized hydroethanolic extract was lower when compared to alcohol in all the evaluation periods, stabilizing after 24 hours, when it was possible to observe high mortality in all concentrations. Another fact observed is the decrease in the value of $\mathrm{LC}_{50}$, with the increase in the period of exposure, observed for the two extracts evaluated. Araújo et al. (2008) analyzing the toxicity of hexane extracts of plants to the workers of Atta laevigata, also verified the decrease of the values of the $\mathrm{LC}_{50}$, with the increase of the periods of exposure, and the same pattern was observed by Souza et al. (2017) in Esenbeckia pumila extracts on Atta laevigata and Acromyrmex balzani.

The mean survival time of the ants was 40.8 hours after contact with the A1 extract, with $20 \%$ surviving individuals until the bioassay was terminated, probably due to the low bioactive content of the extract (Figure 1). 


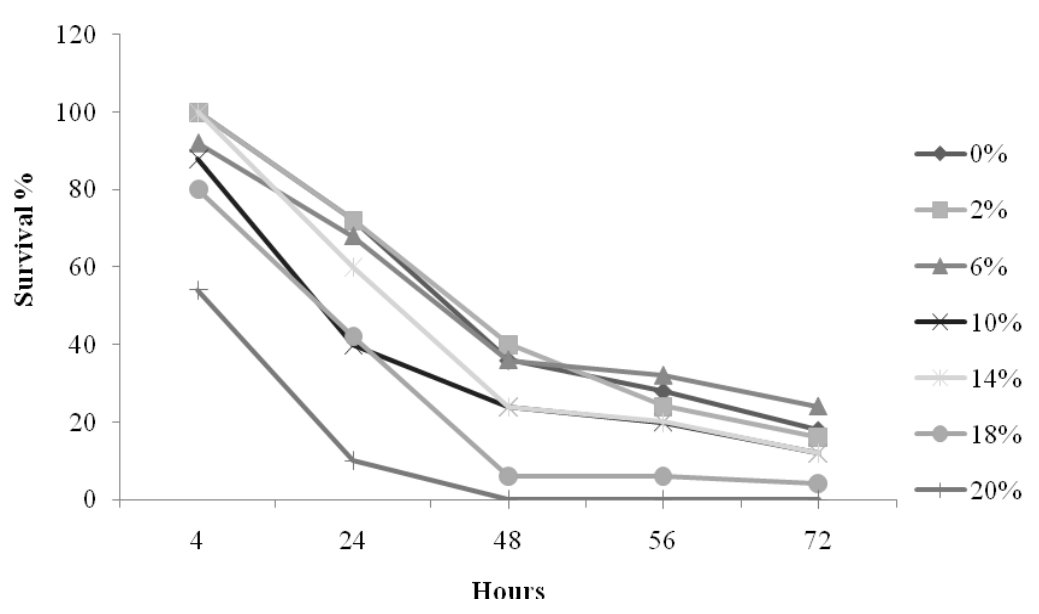

Figure 1. Survival curve of $A$. sexdens rubropilosa individuals, after contact with A1 extract, in the different periods and concentrations.

According to Santos et al. (2013) the result obtained can be explained by the method and time of extraction of bioactive material studied. Extract A1 was already obtained, by means of infusion, after only 15 minutes, with this it can be understood that over a longer period or using another method, the use of the ethanolic extract would be more efficient.

The ant survival analysis after contact with the diluted A2 extract showed that this was lower due to the bioactive content of the extract, as stated by Silva et al. (2008), which indicates that in this type of extract there are higher concentrations (Figure 2). In a study with rotavaporated extract diluted in distilled water from extracts of Derris amazonica Killip. (Timbó), Ipomoea carnea Jacq. (canudo), and Momordica charantia L. (São Caetano melon) Jesus et al. (2013) verified the control effectiveness of Bemisia tabaci (whitefly) nymphs from a concentration of 1,000 milligrams per liter, causing a mortality higher than $50 \%$ of the population, under the concentration of 3,000 milligrams for liter, there were higher percentages of nymphal mortality. For the insecticidal activity of leaf extract of $M$. charantia L (São Caetano melon), however, when applied to 3,000 $\mu \mathrm{g}$. $\mathrm{ML}^{-1}$, did not differ from those that caused higher mortality percentages.

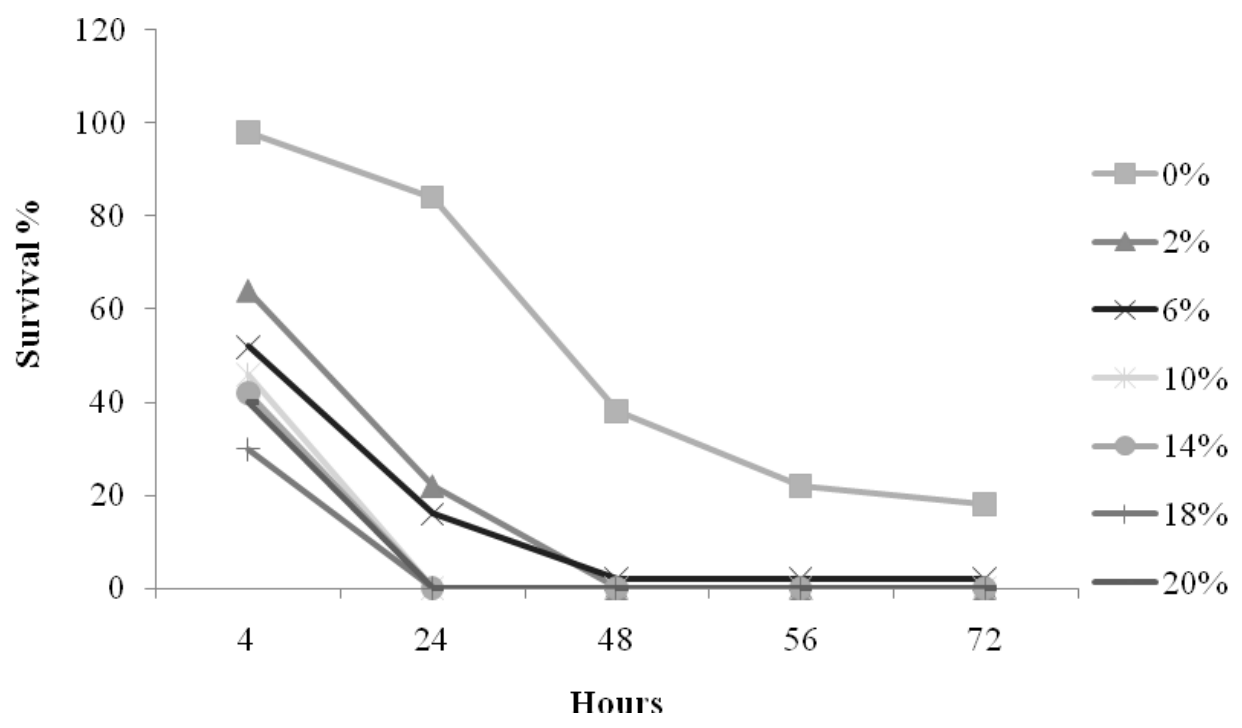

Figure 2. Survival curve of A. sexdens rubropilosa individuals, after contact with extract A2 diluted in distilled water, as a function of the concentrations in the different periods.

The average survival period of the ants was 25.33 hours after contact with the diluted A2 extract. Treatment at $2 \%$ concentration showed survival up to 24 hours. In the $6 \%$ treatment there 
was survival of $2 \%$ until the end of the experiment. For the treatments $10,14,18$, and $20 \%$ there was no survival in the period of 24 hours after topical application, evidencing its mortality after contact with the extract.

Gomes et al. (2016) observed toxic effect by contact of extracts of leaves and branches of Zanthoxylum rhoifolium, bark of Simarouba amara, branches of Aspidosperma spruceanum, and leaves of Casearia arborea on Atta sexdens sexdens. According to these same authors the extracts of plants of the Rutaceae family have toxicity to $A$. sexdens sexdens and also to other insects and should be further studied.

Thus, the hypotheses tested in this study were confirmed. The banana pseudocaule has an insecticidal effect on the results observed in this study, and the hydroethanolic rotaevaporate extract is more efficient than the ethanolic extract.

Thus, this study presents the banana residue as an option for the control of leaf cutting ants, requiring further studies about the most efficient method of application, as well as the analysis of other parts of the plant, and other species cultivated in the country.

\section{CONCLUSIONS}

In the 24-hour period, $90 \%$ mortality was observed at the concentration of $20 \%$ for the A1 extract.

From the $10 \%$ concentration there was $100 \%$ mortality in this same period for extract A2. In the $\mathrm{LC}_{50}$ analysis for 24 hours values of 7.94 and $1.09 \%$ were obtained for ethanolic extract and rotavaporated ethanolic extract respectively. And the $\mathrm{LC}_{50}$ presented a decrease in values after 48 hours for the ethanolic extract presented value of $2.29 \%$.

The concentration of $2 \%$ of the A2 extract caused $100 \%$ mortality at 48 hours, a satisfactory result, which allows the lower consumption of material (extract) in the dilution for later application, due to the presence of insecticidal potential in low concentrations, characterizing the A2 extract as being the most efficient.

\section{ACKNOWLEDGEMENTS}

The authors thank the Professor Edith Eunice Arthur Petrica for the inspiration for this study.

RESUMO: Atualmente, poucos princípios ativos são autorizados pela certificação florestal para o controle de insetos-praga, sendo necessário desenvolver novos produtos, principalmente visando menor impacto ambiental. As plantas são capazes de desenvolver substâncias chamadas metabólitos secundários, amplamente estudadas como uma forma alternativa de controle de pragas. Assim, o objetivo deste trabalho foi avaliar o potencial inseticida de dois extratos de Musa acuminata, no controle de Atta sexdens rubropilosa. Os extratos foram obtidos a partir do pseudocaule de M. acuminata, que foi submetido a secagem e moagem, produzindo dois extratos: etanólico (A1) e hidroalcoólico rotaevaporado (A2). Para a análise da bioatividade dos extratos, foi realizada uma aplicação tópica de um mililitro de cada extrato sobre as formigas, com o auxílio de spray, nas concentrações de: 2, 6, 10, 14, 18 e 20\%, com água destilada (testemunha) aplicada ao teste, verificando-se a mortalidade e a $\mathrm{CL}_{50}$, em diferentes períodos de avaliação. Às 24 horas foi observada mortalidade de $90 \%$ na concentração de $20 \%$ para o extrato A1. A partir da concentração de $10 \%$ houve $100 \%$ de mortalidade nesse mesmo período para o extrato A2, e às 48 horas a concentração de $2 \%$ causou $100 \%$ de mortalidade. $\mathrm{Na}$ análise da $\mathrm{LC}_{50}$ para 24 horas obteve-se valores de 7,94 e 1,09\% para o extrato etanólico e o extrato rotaevaporado respectivamente. $\mathrm{E} \mathrm{a} \mathrm{CL}_{50}$ apresentou diminuição nos valores apartir das 48 horas para o extrato etanólico apresentando valor de 2,29\%. Assim, pode-se concluir que o extrato A2 é o mais eficiente, pois permite o menor consumo de extrato na diluição para posterior aplicação, devido à presença de potencial inseticida em baixa concentração.

PALAVRAS-CHAVE: Resíduos sólidos. Metabólito secundário. Inseticida. Entomologia da floresta.

\section{REFERENCES}

ARAÚJO, M. S.; DELlA LUCIA, T. M. C.; MOREIRA, M. D., PICANÇO, M. C. Toxicidade de extratos hexânicos de plantas às operárias de Atta laevigata e Acromyrmex subterraneus subterraneus (Formicidae: Attini). Revista Brasileira de Agrociência, Pelotas, v. 14, n. 3-4, p. 106-114, 2008.

http://dx.doi.org/10.18539/cast.v14i3.1939 
ARRAIS, L. G.; LYRA, H. F. S.; BATISTA, D. C. A.; COUTINHO, F. N.; SARAIVA, A. M.; PEREIRA, R. C. A.; PISCIOTTANO, M. N. C.; XAVIER, H. S.; MELO, S. J. Atividade antimicrobiana dos extratos metanólicos da raiz, caule e folhas de Croton pulegioides Baill. (Zabelê). Revista Brasileira de Plantas Medicinais, Campinas, v. 16, n. 2, supl. 1, p. 316-322, 2014. http://dx.doi.org/10.1590/1983-084X/12_033

CARVALHO, K. S.; CRUZ, R. C. D.; SILVA, S. L. C.; GUALBERTO, S. A. Atividade larvicida dos extratos aquosos e do hidrolato das folhas de Croton tetradenius sobre o Aedes aegypti. Enciclopédia Biosfera, Goiânia, v. 11, n. 21, p. 2815- 2823, 2015.

DELABIE, J. H. C.; ALVES, H. S. R.; REUSS-STRENZEL, G. M.; CARMO, A. F. R.; NASCIMENTO, I. C. Distribuição das formigas cortadeiras dos gêneros Acromyrmex e Atta no novo mundo. In: DELLA LUCIA, T. M. C. (Eds). Formigas-cortadeiras: da bioecologia ao manejo. Editora UFV: Viçosa, 2011. p. 81-99.

GOMES, M. C. A. R.; PAULA, V. F.; MOREIRA, A. A.; CASTELLANI, M. A.; MACEDO, G. E. L. Toxicity of plant extracts from Bahia, Brazil, to Atta sexdens sexdens (Hymenoptera: Formicidae) workers.

Sociobiology, Feira de Santana, v. 63, n. 2, p. 770-776, 2016.

http://dx.doi.org/10.13102/sociobiology.v63i2.936

HEBLING, M. J. A .; BUENO, O. C.; MARIOTI, P. S.; PAGNOCCA, F. C.; SILVA, O. A. Effects of leaves of Ipomea batatas (Convolvulaceae) on nest development and on respiratory metabolism of leaf-cutting ants Atta sexdens L. (Hym., Formicidae). Journal of Applied Entomology, Göttingen, v. 124, n. 5-6, p. 249- 252, 2000. https://doi.org/10.1046/j.1439-0418.2000.00471.x

JESUS, S. C. P. de; MENDONÇA, F. A. C. de; MOREIRA, J. O. T. Atividade inseticida e modos de ação de extratos vegetais sobre mosca branca (Bemisia tabaci). Revista em Agronegócios e Meio Ambiente, Maringá, v. 6 , n. 1, p. 117-134, 2013.

JUNG, P. H.; SILVEIRA, A. C.; NIERI, E. M.; POTRICH, M.; SILVA, E. R. L.; REFATTI, M. Atividade inseticida de Eugenia uniflora L. e Melia azedarach L. sobre Atta laevigata Smith. Revista Floresta e Ambiente, Seropédica - RJ, v. 20, n. 2, p. 191-196, 2013. http://dx.doi.org/10.4322/floram.2013.015

LIMA NETO, G. A.; KAFFASHI, S.; LUIZ, W. T.; FERREIRA, W. R.; DIAS DA SILVA, Y. S. A.; PAZIN, G. V.; VIOLANTE, I. M. P. Quantificação de metabólitos secundários e avaliação da atividade antimicrobiana e antioxidante de algumas plantas selecionadas do Cerrado de Mato Grosso. Revista Brasileira de Plantas Medicinais, Campinas, v.17, n.4, p. 1069-1077, 2015. http://10.1590/1983-084X/14_161

OLIVEIRA, M. V. de; FRANÇA, E. C. B. de; FEITOSA, R. M.; CORREIA, M. E. F.; QUEIROZ, J. M. Ninhos de Atta sexdens (Hymenoptera: Formicidae) podem afetar a estrutura da assembleia de artrópodes do solo na Mata Atlântica? Iheringia. Série Zoologia, Porto Alegre, v.108, n. 11, 2018.

http://dx.doi.org/10.1590/1678-4766e2018009

RODRIGUES, V. M.; VALENTE, E. C. N.; LIMA, H. M. A.; TRINDADE, R. C. P.; DUARTE, A. G. Avaliação de extratos de Annona muricata L. sobre Aphis craccivora Koch, 1854 (Hemiptera: Aphididae). Revista Brasileira de Agroecologia, Porto Alegre, v. 9, n. 3, p. 75-83, 2014.

SANTOS, P. L.; PRANDO, M. B.; MORANDO, R.; PEREIRA, G. V. N.; KRONKA, A.Z. Utilização de extratos vegetais em proteção de plantas. Enciclopédia Biosfera, Goiânia, v. 9, n. 17, p. 2562-2576, 2013.

SILVA, C. G. V.; ZAGO, H. B.; JÚNIOR, H. J. G. S.; CAMARA, C. A. G. da.; OLIVEIRA, J. V. de; BARROS, R.; SCHWARTZ, M. O. E.; LUCENA, M. F. A. Composition and Insecticidal Activity of the Essential Oil of Croton grewioides Baill. against Mexican Bean Weevil (Zabrotes subfasciatus Boheman). Journal of Essential Oil Research, Messina, v. 20, p. 179-182, 2008. https://doi.org/10.1080/10412905.2008.9699985 
SILVA, F. de A. S. e.; AZEVEDO, C. A. V. de. The Assistat Software Version 7.7 and its use in the analysis of experimental data. African Journal of Agricultural Reserch, Abuja, v. 11, n. 39, p. 3733-3740, 2016. https://doi.org/10.5897/AJAR2016.11522

SOUZA, B. R.; COELHO, G. M., ROCHA, E. C.; JESUS, F. G.; MENEZES, A.C.S; ARAÚJO, M. S. Topical Toxicity of Esenbeckia pumila Extracts on Leaf-Cutting Ants Atta laevigata and Acromyrmex balzani. Journal of Agricultural Science; Alberta, v. 9, n. 12; p.248-258, 2017. https://doi.org/10.5539/jas.v9n12p248

SOUZA, M. D. de, PERES FILHO, O., CALDEIRA, S. F., DORVAL, A., SOUSA, N. J. Desenvolvimento in vitro do fungo simbionte de Atta sexdens rubropilosa Forel, 1908 (Hymenoptera: Formicidae) em meio de cultura com diferentes extratos vegetais. Ciência Rural, Santa Maria, v.42, n.9, p.1603-1609, 2012.

http://dx.doi.org/10.1590/S0103-84782012005000058

SOUZA, O.; FEDERIZZI, M., COELHO, B., WAGNER, T. M.;WISBECK, E. Biodegradação de resíduos lignocelulósicos gerados na bananicultura e sua valorização para a produção de biogás. Revista Brasileira de Engenharia Agrícola e Ambiental, Campina Grande, v.14, n.4, p.438-443, 2010.

http://dx.doi.org/10.1590/S1415-43662010000400014

SOUZA-SILVA, A.; ZANETTI, R.; CARVALHO, G. A.; SANTOS, A.; MATTOS, J. O. S. Preferência de formigas cortadeiras por mudas de eucalipto pulverizadas ou imersas em soluções de extrato pirolenhoso em diferentes concentrações. Scientia Forestalis, Piracicaba, n. 67, p. 9-13, 2005.

TAVARES, M. A.; VENDRAMIM, J. D. Bioatividade da erva-de-santa-maria, Chenopodium ambrosioides L., sobre Sitophilus zeamais Mots. (Coleoptera: Curculionidae). Neotropical Entomology, Londrina, v. 34, n. 2, p. 319-323, 2005. http://dx.doi.org/10.1590/S1519-566X2005000200021

VIGLIANCO, A. I.; NOVO, R. J.; CRAGNOLINI, C. I.; NASSETTA, M.; CAVALLO, A. Antifeedant and repellent effects of extracts of three plants from Córdoba (Argentina) against Sitophilus oryzae (L.) (Coleoptera: Curculionidae). BioAssay, Piracicaba, v. 3, n. 4, p. 1-6, 2008. https://doi.org/10.14295/BA.v3.0.55 